\title{
Analysis of the prevalence of the open bite in the medical records of preventive orthodontics at the Faculdade de Ilhéus
}

Análise dla prevallencia da mordida aberta nos prontuários de ortodontia preventiva da Faculdadle de Illhéus

Análisis de la prevalencia de mordida abierta en la historia clínica de ortodoncia preventiva de la Faculdade de Ilhéus

Maria Luísa Fernandes Godeiro ORCID: https://orcid.org/0000-0001-9033-284X Faculdade de Ilhéus, Brazil E-mail: malufernandes13@hotmail.com

Adolfo de Matos de Carvalho ORCID: https://orcid.org/0000-0002-4421-660X Faculdade de Ilhéus, Brazil

E-mail: adolfodecarvalho@outlook.com

Ana Grasiela da Silva Limoeiro

ORCID: https://orcid.org/0000-0003-4633-720X Faculdade de Ilhéus, Brazil

E-mail: grasielalimoeiro@gmail.com Maria Lúcia Leite

ORCID: https://orcid.org/0000-0001-6175-4242 Faculdade de Ilhéus, Brazil

E-mail: lucialeiteestatistica@gmail.com

Vanessa Barreiros

ORCID: https://orcid.org/0000-0002-8833-7737

Faculdade de Ilhéus, Brazil

E-mail: nessabarreiros@hotmail.com

\begin{abstract}
Objective: To verify the prevalence of open bite in the medical records of preventive orthodontics at the Faculdade de Ilhéus, associating it with the individual's psychological behavior and functional analysis. Material and methods: A cross-sectional study was carried out with 145 medical records of preventive orthodontics of the Faculdade de Ilhéus in the years 2018 and 2019. Result: The prevalence of open bite identified in the medical records of preventive orthodontics of the Faculdade de Ilhéus was $15.8 \%$. The female gender was the majority with $55 \%$, with $61 \%$ of cases of malocclusion. Regarding the dentition that the patient was in, $73.91 \%$ were in mixed dentition, $21.74 \%$ in primary dentition and only $4.35 \%$ in permanent dentition. In the functional analysis observed in the dental document, $40.54 \%$ were oral-nasal breathers, followed by $35.14 \%$ with interposed tongue and abnormal speech was $24.22 \%$. Patients who had an open bite in the psychological behavior item $68.75 \%$ used pacifiers and $31.25 \%$ had the habit of digital sucking. Conclusion: The data collected in this study reinforce the significant prevalence of open bite and the close association with harmful habits and the individual's respiratory, swallowing and phonation physiology. Explanatory measures are necessary for those responsible for the prevention of harmful habits that can cause open bite in children, if the open bite is already present, it should be interfered as soon as possible, as this way the less invasive treatment can be adopted by the orthodontist, enabling a satisfactory regression to the patient.
\end{abstract}

Keywords: Prevalence; Open bite; Malocclusion.

\section{Resumo}

Objetivo: Verificar a prevalência de mordida aberta nos prontuários de ortodontia preventiva da Faculdade de Ilhéus, associando ao comportamento psicológico e a análise funcional do indivíduo. Material e métodos: Realizou-se um estudo transversal com 145 prontuários de ortodontia preventiva da Faculdade de Ilhéus nos anos de 2018 e 2019. Resultado: A prevalência de mordida aberta identificada nos prontuários de ortodontia preventiva da faculdade de Ilhéus foi de $15,8 \%$. O gênero feminino foi maioria com $55 \%$, tendo $61 \%$ dos casos da má oclusão. Em relação a dentição que o paciente se encontrava $73,91 \%$ estavam na dentição mista, $21,74 \%$ na dentição decídua e apenas $4,35 \%$ em dentição permanente. Na análise funcional observada no documento odontológico, $40,54 \%$ eram respirador buco-nasal seguido de $35,14 \%$ com língua interposta e a fonação anormal foi de $24,22 \%$. Os pacientes que possuíam mordida aberta no item de comportamento psicológico $68,75 \%$ faziam o uso de chupeta e $31,25 \%$ tinham o hábito de sucção digital. 
Conclusão: Os dados coletados no presente estudo reforçam a prevalência significativa da mordida aberta e a intima associação com hábitos deletérios e a fisiologia respiratória, de deglutição e fonação do indivíduo. É necessário medidas explicativas aos responsáveis para prevenção de hábitos nocivos que podem causar a mordida aberta em crianças, caso a mordida aberta já esteja presente deve-se interferir o quanto antes, pois assim o tratamento menos invasivo pode ser adotado pelo ortodontista possibilitando uma regressão satisfatória ao paciente.

Palavras-chave: Prevalência; Mordida aberta; Má oclusão.

\section{Resumen}

Objetivo: Verificar la prevalencia de mordida abierta en la historia clínica de ortodoncia preventiva de la Faculdade de Ilhéus, asociándola con el comportamiento psicológico y análisis funcional del individuo. Material y métodos: Se realizó un estudio transversal con 145 historias clínicas de ortodoncia preventiva de la Faculdade de Ilhéus en los años 2018 y 2019. Resultado: La prevalencia de mordida abierta identificada en las historias clínicas de ortodoncia preventiva de la Faculdade de Ilhéus fue del $15,8 \%$. El sexo femenino fue mayoritario con un $55 \%$, con un $61 \%$ de los casos de maloclusión. En cuanto a la dentición en la que se encontraba el paciente, el 73,91\% estaba en dentición mixta, el $21,74 \%$ en dentición temporal y solo el $4,35 \%$ en dentición permanente. En el análisis funcional observado en el documento odontológico, el 40,54\% eran respiradores buco-nasales, seguidos por el 35,14\% con lengua interpuesta y el habla anormal fue del $24,22 \%$. De los pacientes que presentaban mordida abierta en el ítem de conducta psicológica, el 68,75\% utilizaba chupete y el 31,25\% tenía el hábito de chuparse los dedos. Conclusión: Los datos recogidos en este estudio refuerzan la importante prevalencia de mordida abierta y la estrecha asociación con los hábitos nocivos y la fisiología respiratoria, deglución y fonación del individuo. Son necesarias medidas explicativas para los responsables de la prevención de hábitos nocivos que pueden ocasionar la mordida abierta en los niños, si la mordida abierta ya está presente, se debe interferir lo antes posible, ya que de esta forma se puede adoptar el tratamiento menos invasivo por parte del ortodoncista, permitiendo una regresión satisfactoria al paciente.

Palabras clave: Prevalencia; Mordida abierta; Maloclusión.

\section{Introduction}

Over time, the incidence of malocclusion has become a worldwide oral health problem, surpassed only by dental caries and periodontal diseases, and is an alarming problem, especially for orthodontists. (Dias \& Gleiser, 2008). Epidemiological surveys help to understand the prevalence or incidence of a particular disease affecting the population. They are scientific evidence that contributes and encourages the research field to discuss, clarify, and search for less invasive and accessible public health solutions to improve people's quality of life. (Miotto et al., 2016).

The open bite is the negative overbite between the upper and lower teeth. This malocclusion can occur both anteriorly and posteriorly and rarely affects the entire dental arch. Among the existing malocclusions, there is a relevant esthetic and functional involvement with skeletal and dental alterations. Several etiologic factors for the occurrence of an open bite have been discussed in the literature, including dental ankylosis, tooth eruption imbalance, hypertrophic tonsils, oral breathing, and finger sucking or pacifying habits. All of these causes have the potential to interfere with normal development of the face and stomatognathic system. (Henriques et al., 2000).

The anterior open bite is a difficult malocclusion to treat because several etiologic factors may be involved in the changes caused by this condition, in addition to genetic and environmental factors. This malocclusion can cause esthetic and functional disturbances for the patient. (Salehi et al., 2015). Considering this, the aim of the study is to review the prevalence of the open bite in the medical records of preventive orthodontics at the Faculdade de Ilhéus, considering the psychological behavior and functional analysis of the individual.

\section{Methodology}

145 records of preventive orthodontics were selected in 2018 and 2019. The age of the patients ranged from 4 to 13 years, and both genders were included in the present study. Patients'dentition (mixed primary dentition or permanent dentition) was observed. The information on the functional analysis item was examined to determine whether the patient had normal or abnormal speech and swallowing; bucconasal, nasal, or oral breathing; and normal, inserted, or trapped tongue. 
The psychological behavior item was analyzed in the preventive orthodontics records to determine if the patient had a habit of sucking a pacifier and sucking fingers (non-nutritive harmful habits).

Medical records that did not contain information on whether the patient had an open bite, in addition to the functional analysis and psychological behavior items, were excluded from the analysis.

\section{Results}

Documentary recording of preventive orthodontic records was predominant, with 145 preventive orthodontic records in 2018 and 2019 selected. The graphs below show the prevalence of the cases with open bite (Graph1), the distribution by gender (Graph 2), the prevalence of open bite by functional analysis (Graph 3) and the Prevalence of biting and pacifier use/habit of digital sucking (Graph 4).

Graph 1 - Prevalence of patients examined and the number of cases with open bite.

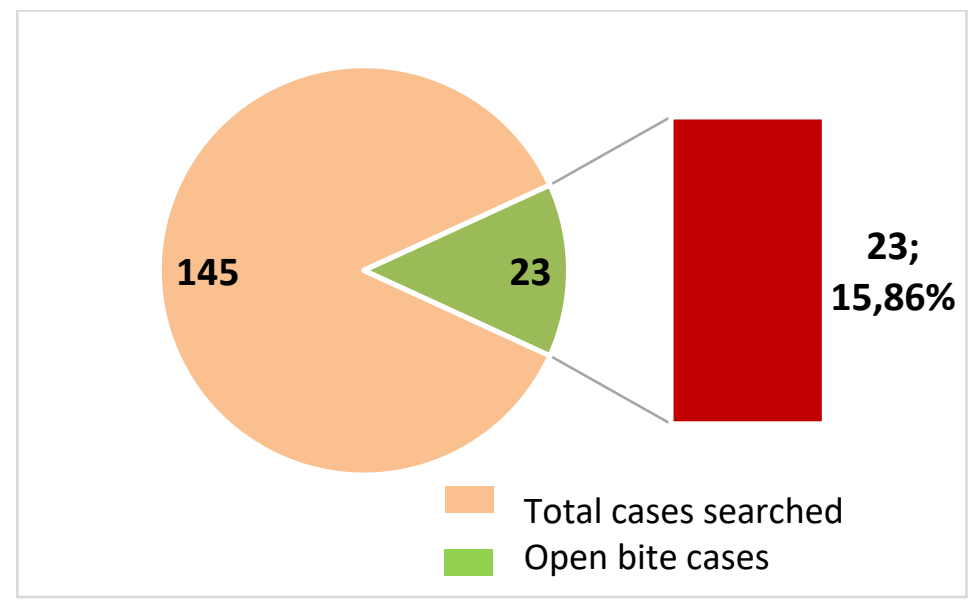

Source: School Clinic of the Faculdade de Ilhéus.

Graph 2 - Distribution by gender of patients.

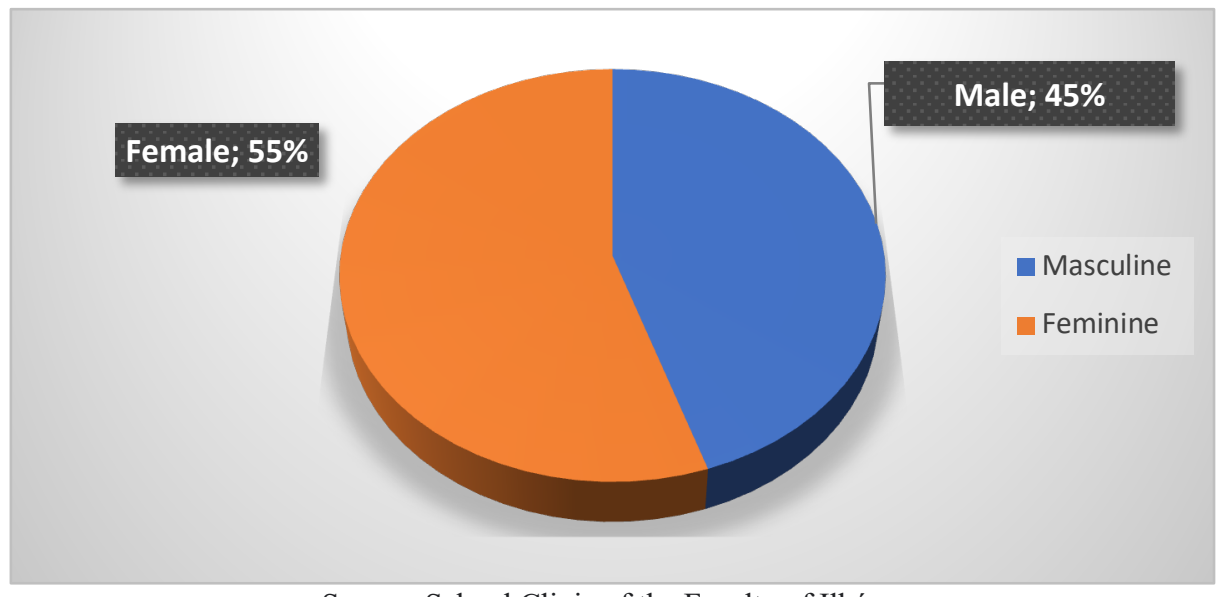

Source: School Clinic of the Faculty of Ilhéus. 
Graph 3 - Prevalence of open bite by functional analysis.

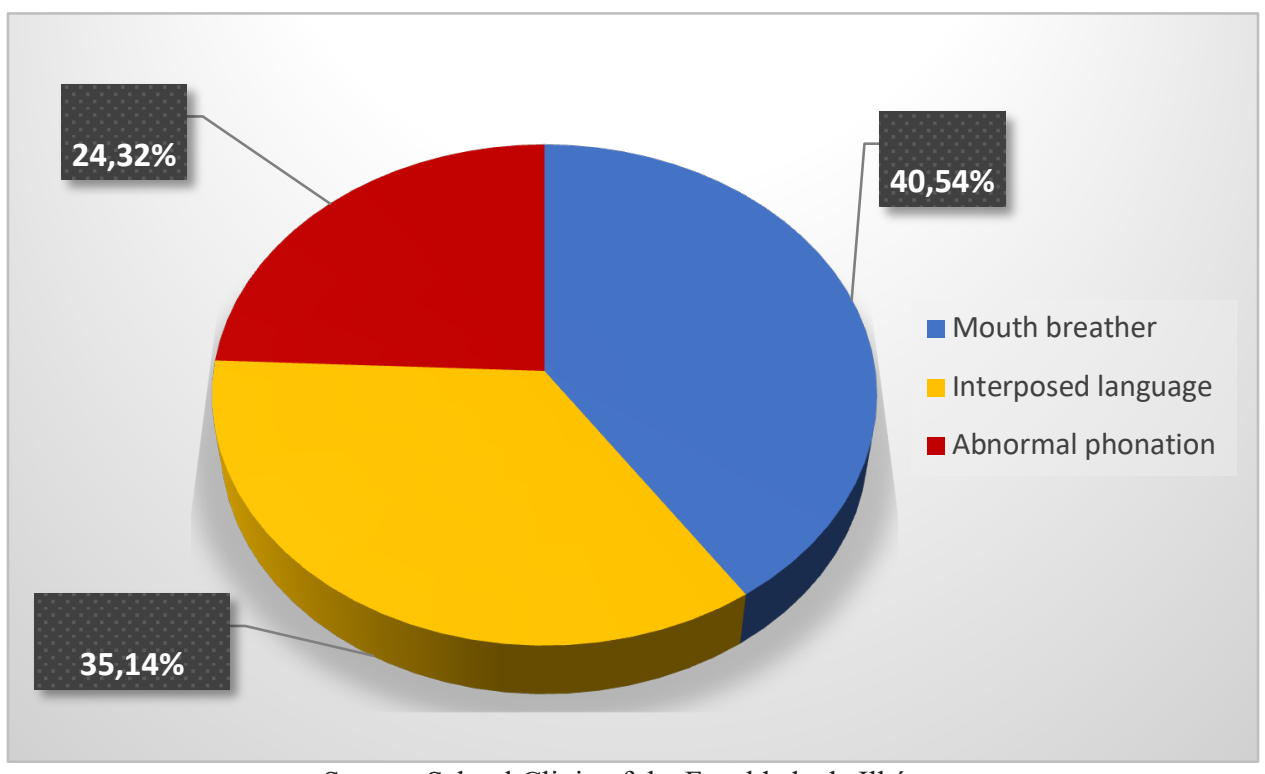

Source: School Clinic of the Faculdade de Ilhéus.

Graph 4 - Prevalence of biting and pacifier use/habit of digital sucking.

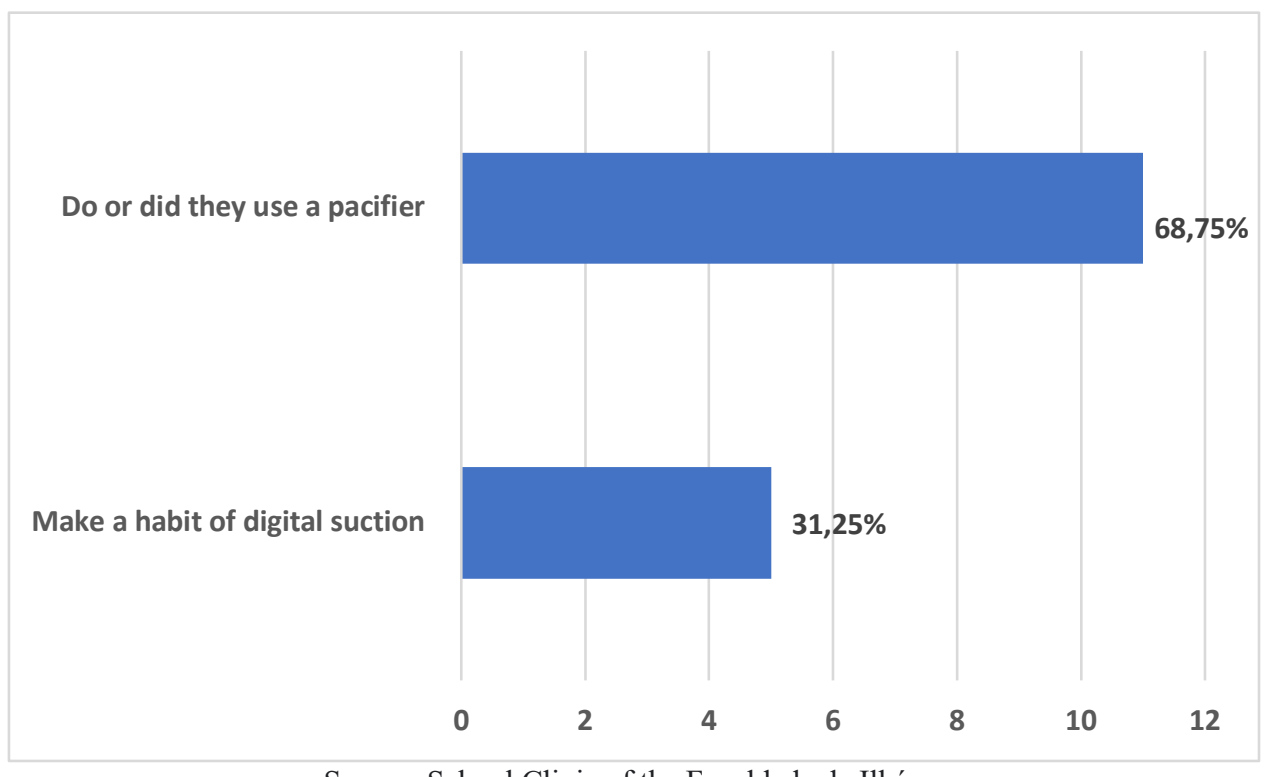

Source: School Clinic of the Faculdade de Ilhéus.

\section{Discussion}

The results of this study show that the prevalence of open bite was $15.86 \%$ and had a significant expression. Moreover, there was a direct and relevant association between malocclusion and patients' psychological behavior and functional analysis. Drumond et al (2011) conducted a study on the prevalence of dental malocclusion in preschool children attending the Faculty of Dentistry of the College of Goiás (FO /UFG). In this study, 116 patients were evaluated and $88.8 \%$ had some type of dental malocclusion, with anterior open bite being the most prevalent (21.55\%). Boeck et al. (2013) conducted a survey in which $26.14 \%$ of subjects had an open bite. Souza Junior et al. (2013) identified $20.97 \%$ of open bite cases in their study, while Carvalho et al. (2019) analyzed the prevalence of open bite and associated factors in preschool children in Salvador- BA and found a prevalence of open bite of $14.02 \%$ of children, confirming the present study. Santos (2018) studied the occurrence of 
malocclusion in pediatric patients treated at the Integrated Dental Clinic of the Recôncavo Baiano. The methodology used was a documentary study of 180 pediatric medical records, in which the prevalence of open bite was $8.5 \%$, which distinguishes the present study due to the definitions of the variables established in the study. Iwasa, Sousa, and Wada (2003) determined a prevalence of $4.20 \%$. Brito, Dias, Gleiser (2009) studied the prevalence of anterior open bite and $7.80 \%$ of the subjects had malocclusion. This differs from the results found in the medical records of preventive orthodontics of the Faculdade de Ilhéus.

Regarding gender, some studies in the literature mention a preference for women, which confirms this study. However, the study by Tibolla et al. (2012) showed that $50.3 \%$ of the children were male and $49.4 \%$ were female. Miotto et al. (2014) studied both sexes in open bite cases, where the distribution was $50 \%$.

Studies on sex ratios and open bites are scarce in the scientific community, and further research on this topic is important. Góis et al (2012) found a prevalence of open bite in mixed dentition of 24.4\%. Lentini-Oliveira et al. (2014) observed that the prevalence of anterior open bite in the mixed dentition ranged from $17 \%$ to $18 \%$. Shalish et al (2013) studied the prevalence of open bite in the mixed dentition and found that only $6.7 \%$ had malocclusion in this dentition, which is in contrast to this study. Tibolla et al (2012) analyzed the prevalence of open bite, finding 34.2\% occurred in the primary dentition, $24.4 \%$ in the mixed dentition, and $15 \%$ in the permanent dentition, which does not agree with the present study. It goes without saying that an early diagnosis favors a less invasive treatment for the patient, since self-correction of the open bite in the primary dentition is still possible up to the first four years of life after the elimination of the harmful habits.

In cases where the patient has an open bite in the mixed dentition, interceptive and corrective orthodontics should be used, which is a less conservative procedure. There are few cases in the literature in which an open bite occurs in the permanent dentition because children often abandon harmful habits before entering this dentition. In the study conducted by Maciel et al. (2005), only $20 \%$ of open bite cases showed oral nasal breathing, which differs from the present study because of the different static parameters. The change in breathing pattern may result from hypertrophy of structures such as adenoids and tonsils, leading to nasal obstruction. Maciel et al (2005) found that $59 \%$ of patients had tongue interposition. In many cases where the patient has an open bite, the change in tongue position represents a morphologic adaptation to the oral environment and may exacerbate malocclusion. An open bite can cause atypical phonation because the tongue protrudes outward or to the side at the time of phonemic articulation.

Multifactorial involvement of other fields such as speech-language pathology and otolaryngology are essential for effective correction of the open bite.

In the study by Pizzol et al (2012), $11 \%$ of preschool children in the city of Araraquara- SP had the habit of digital sucking. On the other hand, Miotto et al. (2014) found a prevalence of the habit of digital sucking of $39.3 \%$ and $36.3 \%$ of children used a pacifier in cases of open bite. In another study, also conducted by Miotto et al. (2016), the habit of digital sucking was only $3.9 \%$ and $29.4 \%$ used a pacifier, which is not consistent with the present study. Colombi et al. (2017) analyzed open biting and harmful habits in children from 9 schools in the city of Nova Venécia- ES, where they found $45.8 \%$ with pacifier use and $14.8 \%$ with finger sucking habits, making this study the closest to the present study. In the present study, most of the patients with open bite had some non-nutritive sucking habit, and this factor may be directly related to the etiology of malocclusion. It is well known that these habits produce a feeling of emotional satisfaction in infants and children, which is often not only achieved through breast milk and is also used as an artifice to soothe and comfort children. Open biting occurs early and is common in children who have the habit of using pacifiers or sucking their fingers. However, it is important to observe the growth pattern of the patient's face and evaluate the intensity, duration, and frequency of the habit (Graber's triad) to provide a guide to the severity of malocclusion. This study was performed with a small sample of medical records, since some documents did not contain records of the patient with or without open bite, functional analysis, and psychological behavior. 
Research, Society and Development, v. 10, n. 14, e116101421821, 2021

(CC BY 4.0) | ISSN 2525-3409 | DOI: http://dx.doi.org/10.33448/rsd-v10i14.21821

\section{Conclusion}

The current study highlights that open bite has epidemiological relevance and shows the relationship between harmful habits and functional analysis and dental malocclusion. Therefore, preventive measures should be implemented in schools, day care centers, and oral health events for those responsible for educating about harmful habits that can cause open bite. In cases where the open bite already exists, the orthodontist must consider the patient's facial growth pattern and heredity, perform interceptive and corrective orthodontics, investigate the causes, and determine if problems with breathing, phonation, or swallowing may be involved in the malocclusion, and recommend multidisciplinary treatment to achieve successful treatment with little chance of recurrence.

\section{References}

Abrão, J., Moro, A., Horliana, R. F., \& Shimizu, R. H. (2014). Ortodontia preventiva: diagnóstico e tratamento. Artes Médicas Editora.

Albuquerque, É. B. D. O. (2016). Mordida aberta anterior na infância: revisão crítica da literatura.

Araujo, J. C. T.F. (2018). Mordida aberta anterior: Etiologia, Diagnóstico e Tratamento.

Artese, A., Drummond, S., Nascimento, J. M. D., \& Artese, F. (2011). Critérios para o diagnóstico e tratamento estável da mordida aberta anterior. Dental Press Journal of Orthodontics, 16(3), 136-161.

Ártico, M. F. M., Bastiani, C., Jock, M. D., \& Kobayashi, E. T. (2004). < b> Prevalência da mordida aberta anterior. Iniciação Científica Cesumar, 6(1), 12-15. Capoani, K. L. (2014). Prevalência da mordida aberta anterior.

Carvalho, A. A. D., Almeida, T. F. D., \& Cangussu, M. C. T. (2021). Prevalência de mordida aberta e fatores associados em pré-escolares de Salvador-BA em 2019. Revista de Odontologia da UNESP, 49.

Carvalho, C. M., da Costa CARVALHO, L. F. P., Forte, F. D. S., do Socorro ARAGÃO, M., \& da COSTA, L. J. (2009). Prevalência de mordida aberta anterior em crianças de 3 a 5 anos em Cabedelo/PB e relação com hábitos bucais deletérios. Pesquisa Brasileira em Odontopediatria e Clínica Integrada, 9(2), 205-210.

da Silva, B. C., dos Santos, D. C. L., Flaiban, E., Negrete, D., \& dos Santos, R. L. (2019). Mordida aberta anterior: origem e tratamento. Revista de Odontologia da Universidade Cidade de São Paulo, 31(1), 68-73.

de Matos, B. S., de Carvalho, E. M. L., da Silva Gonçalves, G., \& da Silva, L. A. H. (2019). Etiologia, diagnóstico e tratamento da mordida aberta anterior na dentadura mista. Revista Rede de Cuidados em Saúde, 13(1).

de Paula Iwasa, E. A., de Sousa, M. D. L. R., \& Wada, R. S. Prevalência e Severidade da Mordida Aberta Anterior em Crianças com Idade de 12 Anos da Região de Piracicaba, Estado de São Paulo-Brasil.

Ferreira, F. V. (1996). Ortodontia: diagnóstico e planejamento clínico. In Ortodontia: diagnóstico e planejamento clínico (pp. 495-495).

Granville-Garcia, A. F., Ferreira, J. M. S., \& Menezes, V. A. D. (2010). Prevalência de mordida aberta anterior e protrusão dentária em pré-escolares da cidade do Recife (PE, Brasil). Ciência \& saúde coletiva, 15, 3265-3270.

JF, C. (2000). Mordida Aberta Anterior: A Importância da Abordagem Multidisciplinar e Considerações sobre Etiologia. Diagnóstico e Tratamento. Apresentação de um Caso Clínico. Rev Dental Press Ortodon Ortop Facial, 2.

Maciel, C. T. V., \& Leite, I. C. G. (2005). Aspectos etiológicos da mordida aberta anterior e suas implicações nas funções orofaciais. Pró-Fono Revista de Atualização Científica, 17, 293-302.

Miotto, M. H. M. D. B., Cavalcante, W. S., Godoy, L. M., Campos, D. M. K. D. S., \& Barcellos, L. A. (2014). Prevalência de mordida aberta anterior associada a hábitos orais deletérios em crianças de 3 a 5 anos de Vitória, ES. Revista CEFAC, 16, 1303-1310.

Montanere. M. (2013). Mordida aberta anterior.

Proffit, W. R. (2013). Ortodontia Contemporânea5: Ortodontia Contemporânea. Elsevier Health Sciences.

Schwertner, A., Nouer, P. R. A., Garbui, I. U., \& Kuramae, M. (2007). Prevalência de maloclusão em crianças entre 7 e 11 anos em Foz do Iguaçu, PR. $R G O$ (Porto Alegre), 155-161

Thomaz, E. B. A. F., \& Valença, A. M. G. (2005). Prevalência de má-oclusão e fatores relacionados à sua ocorrência em pré-escolares da cidade de São LuísMA-Brasil. RPG Rev Pós Grad, 12(2), 212-21.

Vieira, I. C. C., Vieira, I. C., de Azeredo, M. S., Jardim, L. S. V., do Prado, J. P., Reis, J. A. B., \& Lessa, A. M. G. (2018). Tratamento de mordida aberta anterior: Uma revisão de literatura. ID on line Revista de psicologia, 12(42), 984-995. 